\title{
SISTEM KENDALI ANTI SWAY OVERHEAD CRANE
}

\author{
Mohammad joko Akbar', Mohammad Ramdhani', Agung Surya Wibowo \\ 1, 2, 3 Prodi S1 Teknik Elektro, Fakultas Teknik Elektro, Universitas Telkom \\ 1jokoakbar@students.telkomuniversity.ac .id, ${ }^{2}$ mohamadramdhani@telkomuniversity.ac.id, \\ 3agungsw@telkomuniversity.ac.id
}

\begin{abstract}
Abstrak
Persaingan yang ketat dalam bidang industri membuat banyak perusahaan berlomba-lomba berinovasi untuk meningkatkan produktivitas pabriknya. Salah satunya dalam hal mobilitas alat berat, yaitu pengoperasian crane. Sway merupakan permasalahan yang kerap timbul pada saat pengoperasian crane. Sway adalah ayunan dari beban yang ditimbulkan saat motor crane melakukan percepatan atau perlambatan. Pengoperasian crane yang aman dan terkendali merupakan sesuatu yang diingikan oleh perusahaan.
\end{abstract}

Anti Sway Overhead Crane merupakan suatu inovasi yang dibutuhkan oleh perusahaan yang berlatar belakang alat berat dalam pengoperasian crane. Anti Sway Overhead Crane merupakan prototipe yang menggunakan sistem anti sway dalam mengatasi sway yang terjadi pada saat pengoperasian crane. Sistem anti sway dirancang dengan metode sistem kendali Proportional Derivative. Sistem anti sway ini memanipulasi pergerakan arah motor berdasarkan sway yang terjadi pada beban. Kecepatan motor juga diatur berdasarkan besar sudut sway. Sistem kendali Proportional Derivative akan mempercepat rise time dan settling time sistem.

Pengujian yang dilakukan adalah pengujian pengoperasian prototipe crane dengan kondisi tanpa sistem anti sway dan dengan sistem anti sway. Pada dua kondisi ini akan dilihat perbedaannya. Pada pengujian yang dilakukan, terlihat terdapat perbedaan waktu osilasi yang terjadi. sistem anti sway bekerja dengan baik dalam mengurangi waktu osilasi yang terjadi pada beban. Hal ini membuktikan bahwa sistem mempercepat kestabilan benda pada saat sway terjadi.

Kata Kunci: Overhead Crane, Arduino UNO, Sistem Kendali PD, Pendulum.

\section{Abstract}

Intense competition in the field of industry many companies are competing to innovate to improve the productivity of the factory. One of them in terms of machine mobility, which is the operation crane. Sway is a problem that often arise during crane operation. Sway is a swing from being generated when a motor crane accelerates or decelerates. Safe and controlled crane operation is something the company wants.

Anti Sway Overhead Crane is an innovation needed by companies with heavy equipment background in crane operation. Anti Sway Overhead Crane is a prototype that uses anti sway system to overcome sway that occurs during crane operation. The anti sway system is designed by Proportional Derivative control system method. This anti sway system manipulates the motion of the motor direction based on sway that occurs at the load. The speed of the motor is also arranged based on the large sway angle. Proportional Derivative control system will accelerate the rise time and settling time of the system.

Testing conducted is testing the operation of prototype crane with condition without anti sway system and with anti sway system. In these two conditions will be seen the difference. In the test performed, there is a difference in oscillation time that occurs. The anti sway system works well in reducing the oscillation time that occurs in the load. This proves that the system accelerates the stability of the object when it happens.

Keywords: Overhead Crane, Arduino UNO, PD Controller, Pendulum.

\section{Pendahuluan}

Crane merupakan alat yang sangat popular dalam bidang industri. Pengoperasian crane biasanya dilakukan untuk memindahkan dan mengangkut barang berat.
Perusahaan yang banyak menggunakan crane salah satunya adalah perusahaan mobil, perusahaan besi, perusahaan mesin dan sebagainya.

Tentulah perusahaan ini menginginkan crane yang aman dan mudah untuk dikendalikan dalam 
pengoperasiannya. Inovasi terkait crane yang dinginkan perusahaan pun terus berkembang.

Banyak pengembangan yang dilakukan dalam mewujudkan crane yang sesuai. Salah satu pengembangan yang paling populer adalah pengembangan di bidang sway (ayunan) pada beban. Contoh pengembangan yang sudah ada adalah Liji Ramesan Santhi, Laila Beebi M, (2014) "Position Control and Anti-Swing Control of Overhead Crane Using LQR", Zhao, Y., \& Gao, H. (2012). "Fuzzymodel-based control of an overhead crane with input delay and actuator saturation." Dan masih banyak lagi. Pada saat pengoperasian crane, akan terjadi percepatan dan perlambatan motor crane.

Dengan percepatan dan perlambatan yang terjadi maka timbul sway pada beban yang diangkut. Sway pada beban merupakan hal yang klasik dan paling menantang dalam permasalahan pengoperasian crane. Dikarenakan sway pada beban berisiko mengakibatkan kerusakan properti perusahaan dan meningkatkan tingkat kecelakaan kerja. Para pekerja biasanya hanya mengandalkan intuisi dan pengalaman dalam mengoperasikan crane.

Sistem anti sway dapat menjadi solusi dalam permasalahan sway pada crane. Sistem anti sway bekerja dengan memanipulasi pergerakan motor crane.Sistem anti sway dapat dengan cepat mengurangi dan menghilangkan sway pada pengoperasian crane. Di dalam sistem anti sway membutuhkan sistem kendali yang sesuai dengan permasalahan yang terjadi. Sistem kendali yang dibutuhkan merupakan sistem kendali yang memiliki respon yang tinggi serta dapat memproses beberapa input sekaligus.

\section{Dasar Teori}

\subsection{Perancangan Sistem}

Desain sistem atau perancangan sistem adalah merancang atau mendesain suatu sistem yang baik, yang isinya adalah langkah-langkah operasi dalam proses pengolahan data dan prosedur untuk mendukung operasi sistem. Desain ini digunakan sebagai acuan gambaran umum sistem atau mendefiniskan cara kerja sistem secara singkat dan umum. Perancangan ini terdiri dari diagram blok serta fungsi dan fitur.

\subsubsection{Perancangan Sistem Perangkat Keras}

Pada Gambar 1, diperlihatkan bahwa prototipe dibuat dengan menggunakan mikrokontroler, power supply, driver motor L298N, MPU 6050/GY-87, pengendali manual, dan dua buah motor DC. Sebuah mikrokontroler digunakan sebagai otak pengoperasian sistem yang akan dibuat.
Mikrokontroler akan menjadi pusat dan penghubung antara masukan dan keluaran sistem. Platform mikrokontroler yang akan digunakan adalah Arduino Mega 2560. Power supply digunakan sebagai penyuplai sumber listrik untuk mikrokontroler. Driver Motor L298N juga digunakan sebagai penghubung antara motor dan mikrokontroler. Motor yang digunakan merupakan motor DC 12 volt. Motor DC yang digunakan berjumlah 2 buah. Untuk mengendalikan pergerakan crane sistem menggunakan pengendali analog. Sensor MPU6050 juga digunakan untuk mendapatkan nilai sudut yang akan digunakan dalam perhitungan.

\subsubsection{Perancangan Sistem Perangkat Lunak}

Perancangan perangkat lunak sistem anti sway diprogram menggunakan bahasa pemrograman Arduino, yaitu bahasa $\mathrm{C}$ yang meliputi pengaturan PWM, polaritas tegangan motor DC, MPU 6050(sensor gyroscope dan sensor accelerometer), dan sistem anti sway.

Pada Gambar 2 dijelaskan bagaimana sistem akan bekerja pada saat pengoperasian crane. Start merupakan awal sistem dijalankan. Setelah sistem dijalankan maka sistem akan melakukan inisialisasi berupa inisialisasi push button, sensor, dan pin masukan dan keluaran pada arduino. Selanjutnya sistem akan membaca sensor yang sudah dikalibrasi pada proses inisialisasi.

Setelah membaca nilai sensor maka sistem akan membaca masukan dari push button. Jika terdapat masukan dari push button maka motor akan dijalankan sesuai dengan masukan yang diterima. Setelah itu sistem kendali PD akan memproses sudut yang masuk kedalam sistem.

Setelah itu sistem akan kembali membaca sudut yang diterima oleh sensor, lalu sistem akan membaca masukan dari push button, jika tidak ada masukan dari push button maka motor akan dijalankan sesuai dengan keluaran yang dihasilkan oleh proses sistem kendali PD. Sistem akan terusmenerus dalam proses looping. Pada intinya sistem kendali PD akan menyesuaikan pergerakan motor dan kecepatan motor DC sesuai dengan arah dan besar sudut yang terjadi pada beban.

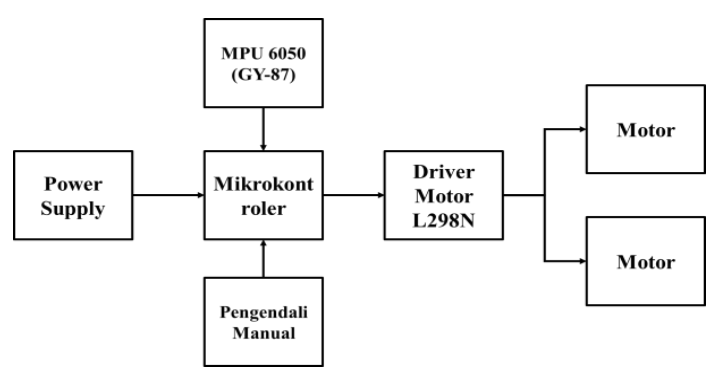

Gambar 1. Desain Perangkat Keras 


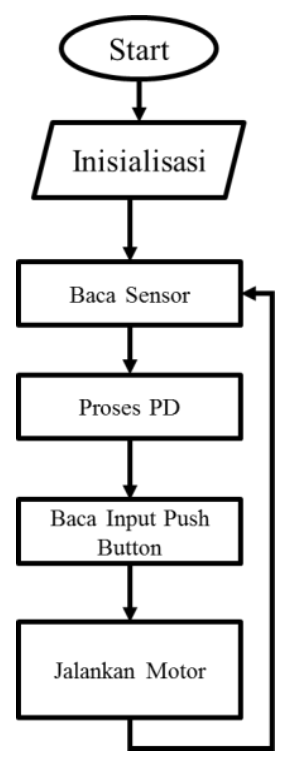

\section{Gambar 2. Desain Perangkat Lunak Sistem}

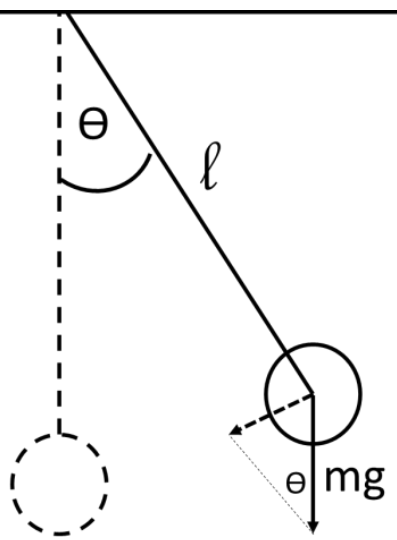

\section{Gambar 3. Ilustrasi Gerakan Pendulum Sederhana}

\section{Proportional Derivative (PD)}

Kendali PD merupakan sebuah sistem yang menggabungkan proportional dan derivative. Kendali PD menghitung nilai eror secara terusmenerus untuk sebagai pembanding antara set point dengan nilai variabel proses yang terukur. Pada aksi kendali proportional, keluaran sistem kendali akan berbanding lurus dengan masukna dan eror, dan mengahasilkan tanggapan yang cepat. Akan tetapi overshoot meningkat sehingga sistem cukup bermasalah saat awal beroperasi. Sedangkan aksi derifative bekerja sesuai laju perubahan eror. Oleh karena itu, kendali ini berfungsi mereduksi laju perubahan eror sehingga menjaga kestabilan sistem.[1]

Kendali proportional adalah metode pengendali yang memberikan gain atau penguatan secara langsung kepada sistem untuk mempengaruhi keluaran sistem. Derivative digunakan bersama dengan proportional sebagai kompensator yang memperbaiki nilai keluaran sistem sehingga mempercepat respon transien sistem.

Persamaan umum sebuah PD adalah sebagai berikut:

$$
U(t)=K p e(t)+K d \frac{\operatorname{de}(t)}{d t}
$$

Dari Persamaan daiat maka bias didapat fungsi alihnya yaitu sebagai berikut:

$$
\frac{\mathrm{U}(\mathrm{s})}{\mathrm{E}(\mathrm{s})}=\mathrm{Kp}+\mathrm{Kd} \mathrm{S}
$$

$\mathrm{U}(\mathrm{t})=$ Keluaran kendali

$\mathrm{e}(\mathrm{t})=$ Selisih antara set point dengan keluaran

$\mathrm{Kp} \quad=$ Konstanta Proportional

$\mathrm{Kd}=$ Konstanta Derivative $=\mathrm{Kp} \times \mathrm{Td}$

$\mathrm{Td}=$ Waktu Derivative

\section{Pemodelan Pendulum}

Untuk mendapatkan nilai $\mathrm{Kp}$ dan $\mathrm{Kd}$ dalam sistem kendali Proportional Derivative, pendekatan yang dilakukan adalah dengan melihat pemodelan pendulum. Osilasi sway yang terjadi di dalam sistem overhead crane dapat diperkirakan dengan pemodelan osilasi pada pendulum sederhana. Pada Gambar 3 diperlihatkan ilustrasi gerakan pendulum sederhana

Untuk gerakan Untuk gerakan rotasi, $\tau=\mathrm{I} \alpha$, dimana $\alpha=\ddot{\theta}$ (percepatan sudut), maka

$$
\begin{array}{r}
-(\mathrm{mg} \sin \theta) \mathrm{l}=\mathrm{I} \ddot{\theta}=\mathrm{ml} \ddot{\theta} \\
-\mathrm{g} \sin \theta=1 \ddot{\theta} \\
\ddot{\theta}+\frac{\mathrm{g}}{1} \sin \theta=0
\end{array}
$$

Dimana

$\mathrm{g}=$ gravitasi

$1=$ panjang tali

$\ddot{\theta}=$ percepatan sudut

$\theta=$ sudut

Untuk $\theta$ yang kecil, $\sin \theta \approx \theta$, maka persamaannya akan menjadi

$$
\ddot{\theta}+\frac{\mathrm{g}}{1} \theta=0
$$

Dari persamaan diatas dapat dijadikan fungsi transfer yaitu

$$
\begin{gathered}
\frac{\mathrm{d}^{2} \theta}{\mathrm{dt}^{2}}+\frac{\mathrm{g}}{1} \theta=\mathrm{T} \\
\left(\mathrm{s}^{2}+\frac{\mathrm{g}}{1}\right) \theta(\mathrm{s})=\mathrm{T}(\mathrm{s})
\end{gathered}
$$




$$
\frac{\theta(\mathrm{s})}{\mathrm{T}(\mathrm{s})}=\frac{1}{\left(\mathrm{~s}^{2}+\frac{\mathrm{g}}{1}\right)}
$$

Persamaan (4) sama dengan persamaan osilasi teredam harmonik sederhana:

$$
\ddot{\mathrm{x}}+\frac{\mathrm{k}}{\mathrm{m}} \mathrm{x}=0
$$

Periode osilasi untuk osilasi harmonik sederhana ialah

$$
\ddot{\mathrm{x}}+\frac{\mathrm{k}}{\mathrm{m}} \mathrm{x}=0
$$

Oleh karena itu periode untuk pendulum sederhana adalah

$$
\mathrm{T}=2 \pi \sqrt{\frac{1}{\mathrm{~g}}}
$$

Dimana

$\mathrm{T}=$ periode osilasi

$1=$ panjang tali

$\mathrm{g}=$ gravitasi

\section{Pengujian dan Analisis}

\subsection{Penentuan nilai Kp dan Kd menggunakan MATLAB}

Dalam metode sistem kendali Proportional Derivative nilai $\mathrm{Kp}$ dan $\mathrm{Kd}$ haruslah ditentukan terlebih dahulu. Nilai $\mathrm{Kp}$ dan $\mathrm{Kd}$ dapat diperoleh melalui beberapa cara salah satunya adalah dengan menggunakan bantuan perangkat lunak MATLAB. Salah satu program di perangkat lunak MATLAB adalah simulink. Dengan bantuan simulink, persamaan pendulum sederhana yang sudah didapat, disimulasikan dan didapatkan hasil nilai $\mathrm{Kp}$ dan $\mathrm{Kd}$. Pada Gambar 4 menunjukan hasil simulasi sistem sebelum ditambahkan sistem kendali Proportional Derivative. Pada Gambar 5 menunjukan hasil simulasi sistem dengan menambahkan sistem kendali Proportional Derivative. Setelah ditambahkan sistem kendali Proportional Derivative maka didapat rise time sebesar 0.328 detik, overshoot sebesar 1.1 derajat, settling time sebesar 4.9 detik, peak time berada pada detik 0.41 dan steady state error sebesar 0.14 derajat.

\subsection{Pengujian Menggunakan Pengendali}

\section{Manual}

Pengujian ini dilakukan untuk mengetahui

bagaimana respon sistem terhadap sway yang timbul akibat penggunaan pengendali manual. Pengujian ini akan dibagi menjadi 8 pengujian. Yaitu:

a. Pengujian Menggerakan Motor ke Arah Axis X Positif dan Axis Y Positif b. Pengujian Menggerakan Motor ke Arah Axis X Negatif dan Axis Y Negatif

c. Pengujian Menggerakan Motor ke Arah Axis Y Negatif

d. Pengujian Menggerakan Motor ke Arah Axis Y Positif

e. Pengujian Menggerakan Motor ke Arah Axis X Positif dan Axis Y Negatif

f. Pengujian Menggerakan Motor ke Arah Axis X Negatif dan Axis Y Positif

g. Pengujian Menggerakan Motor ke Arah Axis X Positif

h. Pengujian Menggerakan Motor ke Arah Axis X Negatif

Hasil yang didapat adalah berupa data sudut dari axis $\mathrm{x}$ dan axis y. Dari data yang didapat akan dibuat grafik dengan format sudut terhadap waktu. Grafik yang ditampilkan menunjukan osilasi sudut yang terjadi ketika pengujian dilakukan terhadap berapa lama waktu yang dibutuhkan untuk mencapai keadaan stabil. Sudut yang ditampilkan pada grafik merupakan sudut dalam bentuk derajat dan waktu yang ditunjukan dalam grafik merupakan waktu dalam hitungan mikro detik. Berikut adalah beberapa pengujian yang dilakukan.

A. Pengujian Menggerakan motor kearah axis $\mathrm{x}$ positif dan axis y positif

Grafik yang ditampilkan merupakan grafik sudut(derajat) terhadap waktu(mikro detik). Garis berwarna biru merupakan sudut yang didapat dari axis $\mathrm{x}$ dan garis berwarna jingga merupakan sudut yang didapat dari axis $y$.

Hasil pengujian pada Gambar 6 menunjukan osilasi sway pada beban tanpa sistem anti sway dengan menggunakan pengendali manual

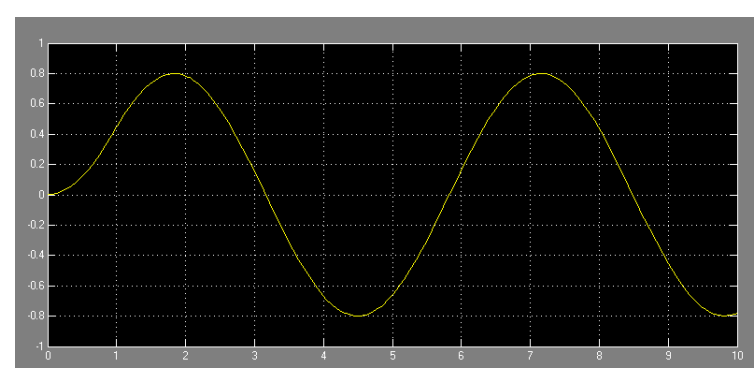

Gambar 4. Hasil Simulasi Pendulum Sederhana

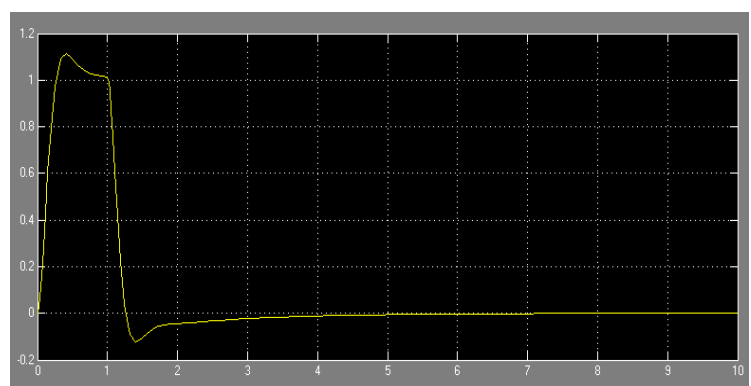

Gambar 5. Hasil Simulasi Sistem Setelah Penambahan Sistem Kendali Proportional Derivative 


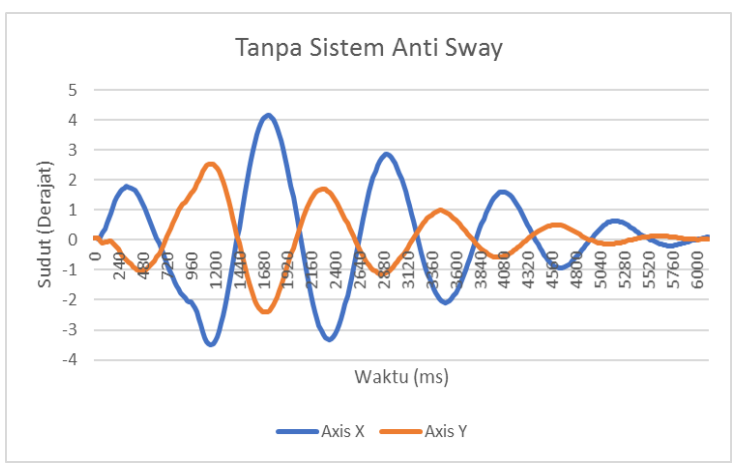

Gambar 6. Sudut Sway pada Beban Tanpa Sistem Anti Sway dengan Pengendali Manual Menggerakan Motor ke Arah Axis X Positif dan Axis Y Positif

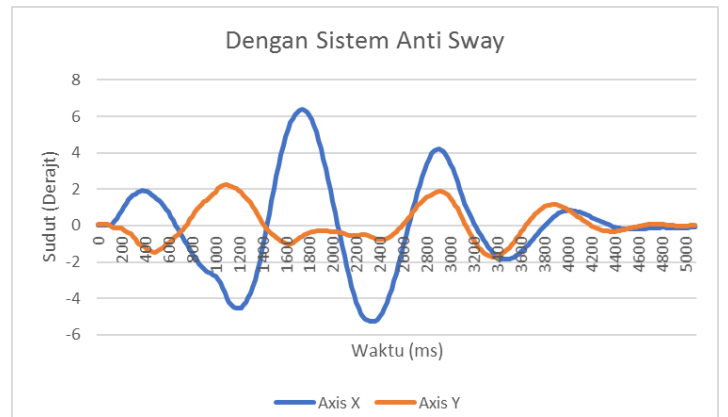

Gambar 7. Sudut Sway pada Beban dengan Sistem Anti Sway dengan Pengendali Manual Menggerakan Motor ke Arah Axis X Positif dan Axis Y Positif

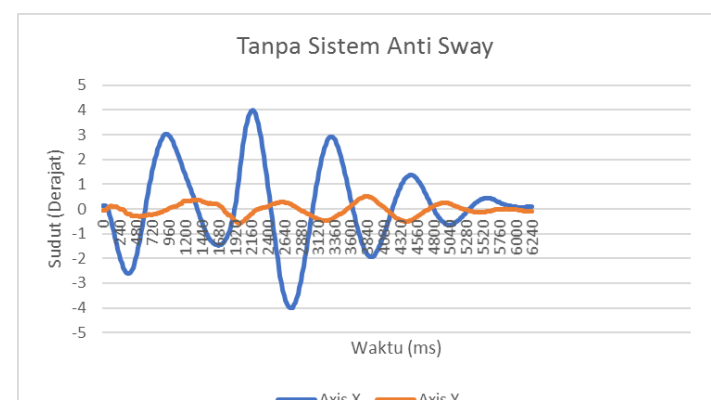

Gambar 8. Sudut Sway pada Beban Tanpa Sistem Anti Sway dengan Pengendali Manual Menggerakan Motor ke Arah Axis Y Negatif

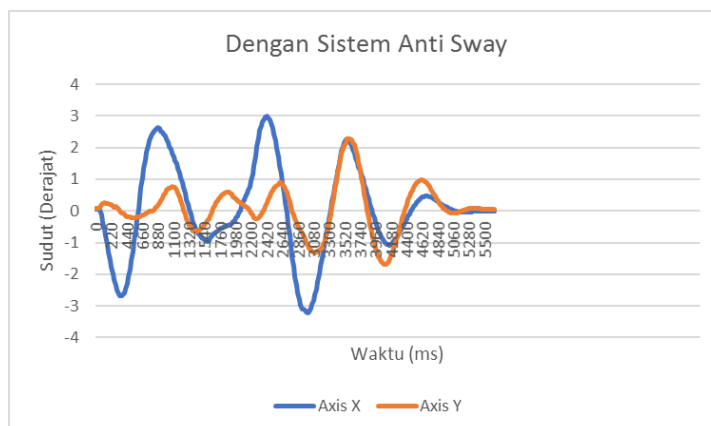

Gambar 9. Sudut Sway pada Beban Dengan Sistem Anti Sway dengan Pengendali Manual Menggerakan Motor ke Arah Axis Y Negatif
Tabel 1. Tabel Hasil Pengujian Sistem Anti Sway

\begin{tabular}{|c|c|c|c|c|}
\hline \multicolumn{5}{|c|}{ Menggunakan Pengendali Manual } \\
\hline \multirow{2}{*}{ No. } & \multirow{2}{*}{ Pengujian } & \multicolumn{2}{|c|}{$\begin{array}{l}\text { Hasil Akhir Pengujian } \\
(\mathrm{ms})\end{array}$} & \multirow{2}{*}{$\begin{array}{c}\text { Perbedaan } \\
\text { Waktu } \\
(\mathrm{ms})\end{array}$} \\
\hline & & $\begin{array}{c}\text { Tanpa Sistem } \\
\text { Anti Sway }\end{array}$ & $\begin{array}{c}\text { Dengan Sistem } \\
\text { Anti Sway }\end{array}$ & \\
\hline 1 & $\begin{array}{l}\text { Pengujian Menggerakan } \\
\text { Motor ke Arah Axis X } \\
\text { Positif dan Axis Y Positif }\end{array}$ & 6000 & 5000 & 1000 \\
\hline 2 & $\begin{array}{c}\text { Pengujian Menggerakan } \\
\text { Motor ke Arah Axis X } \\
\text { Negatif dan Axis Y } \\
\text { Negatif } \\
\end{array}$ & 7000 & 6000 & 1000 \\
\hline 3 & $\begin{array}{c}\text { Pengujian Menggerakan } \\
\text { Motor ke Arah Axis Y } \\
\text { Negatif }\end{array}$ & 6240 & 5500 & 740 \\
\hline 4 & $\begin{array}{c}\text { Pengujian Menggerakan } \\
\text { Motor ke Arah Axis Y } \\
\text { Positif }\end{array}$ & 5200 & 4680 & 520 \\
\hline 5 & $\begin{array}{c}\text { Pengujian Menggerakan } \\
\text { Motor ke Arah Axis X } \\
\text { Positiff dan Axis Y } \\
\text { Negatif }\end{array}$ & 5720 & 4320 & 1400 \\
\hline 6 & $\begin{array}{c}\text { Pengujian Menggerakan } \\
\text { Motor ke Arah Axis X } \\
\text { Negatif dan Axis Y } \\
\text { Positif }\end{array}$ & 6380 & 5720 & 660 \\
\hline 7 & $\begin{array}{l}\text { Pengujian Menggerakan } \\
\text { Motor ke Arah Axis X } \\
\text { Positif }\end{array}$ & 4500 & 3000 & 1500 \\
\hline 8 & $\begin{array}{l}\text { Pengujian Menggerakan } \\
\text { Motor ke Arah Axis X } \\
\text { Negatif }\end{array}$ & 5200 & 5200 & 0 \\
\hline
\end{tabular}

Hasil pengujian pada Gambar 7 menunjukan osilasi sway pada beban dengan sistem anti sway dengan menggunakan pengendali manual. Dari Gambar 6 dan Gambar 7 didapat kesimpulan bahwa pada pengujian dengan menggerakan motor ke arah axis $\mathrm{x}$ positif dan y positif, sistem mengurangi waktu osilasi untuk mencapai keadaan stabil sebesar 1000 ms.

\section{B. Pengujian menggerakan y negatif}

Grafik yang ditampilkan merupakan grafik sudut(derajat) terhadap waktu(mikro detik). Garis berwarna biru merupakan sudut yang didapat dari axis $\mathrm{x}$ dan garis berwarna jingga merupakan sudut yang didapat dari axis y. Hasil pengukuran sudut sway pada beban ketika tidak dipasang sistem anti sway.

Hasil pengujian pada Gambar 8 menunjukan osilasi sway pada beban tanpa sistem anti sway dengan menggunakan pengendali manual. Hasil pengujian pada Gambar 9 menunjukan osilasi sway pada beban dengan sistem anti sway dengan menggunakan pengendali manual. Dari Gambar 8 dan Gambar 9 didapat kesimpulan bahwa pada pengujian dengan menggerakan motor ke arah axis y negatif, sistem mengurangi waktu osilasi untuk mencapai keadaan stabil sebesar $740 \mathrm{~ms}$.

Dari 8 pengujian masing-masing akan dibagi menjadi 2 pengujian yaitu pengujian menggunakan sistem anti sway dan tanpa menggunakan sistem anti 
sway. Tabel 1 merupakan hasil pengujian sistem anti sway menggunakan pengendali manual.

Data dari Tabel 1 menunjukan bahwa sistem anti sway bekerja dengan baik, yaitu mengurangi waktu yang diperlukan dari keadaan sway sampai keadaan sudut stabil. Nilai rata-rata perbedaan antara dengan menggunakan sistem anti sway dan tanpa menggunakan anti sway diatas adalah $852,5 \mathrm{~ms}$.

\subsection{Pengujian Tanpa Menggunakan Pengendali Manual}

Pengujian ini dilakukan untuk mengetahui bagaimana respon sistem terhadap sway yang timbul akibat dorongan manual terhadap beban. Pengujian ini akan dibagi menjadi 8 pengujian. Yaitu:

a. Pengujian sudut axis $x$ positif dan axis y positif

b. Pengujian sudut axis $\mathrm{x}$ negatif dan axis $\mathrm{y}$ negatif

c. Pengujian dengan axis $\mathrm{x}$ mendekati nol dan axis y negatif

d. Pengujian dengan axis $\mathrm{x}$ mendekati nol dan axis y positif

e. Pengujian sudut axis $\mathrm{x}$ positif dan axis $\mathrm{y}$ mendekati nol

f. Pengujian sudut axis $\mathrm{x}$ negatif dan axis $\mathrm{y}$ mendekati nol

g. Pengujian sudut axis $x$ positif dan axis $y$ negatif

h. Pengujian sudut axis $\mathrm{x}$ negatif dan axis $\mathrm{y}$ positif

Hasil yang didapat adalah berupa data sudut dari axis $\mathrm{x}$ dan axis y. Dari data yang didapat akan dibuat grafik dengan format sudut terhadap waktu. Grafik yang ditampilkan menunjukan osilasi sudut yang terjadi ketika pengujian dilakukan terhadap berapa lama waktu yang dibutuhkan untuk mencapai keadaan stabil. Sudut yang ditampilkan pada grafik merupakan sudut dalam bentuk derajat dan waktu yang ditunjukan dalam grafik merupakan waktu dalam hitungan mikro detik.

A. Pengujian sudut axis $x$ positif dan axis y positif

Grafik yang ditampilkan merupakan grafik sudut(derajat) terhadap waktu(mikro detik). Garis berwarna biru merupakan sudut yang didapat dari axis $\mathrm{x}$ dan garis berwarna jingga merupakan sudut yang didapat dari axis y. Pengujian yang akan dilakukan adalah mengatur agar sudut dari axis $\mathrm{x}$ positif dan axis y positif diberikan pada beban.

Hasil pengujian pada Gambar 10 menunjukan osilasi sway pada beban tanpa sistem anti sway dengan menggunakan pengendali manual. Hasil pengujian pada Gambar 11 menunjukan osilasi sway pada beban dengan sistem anti sway dengan menggunakan pengendali manual. Dari Gambar 10 dan Gambar 11 didapat kesimpulan bahwa pada pengujian dengan menggerakan motor ke arah axis $\mathrm{x}$ positif dan y positif, sistem mengurangi waktu osilasi untuk mencapai keadaan stabil sebesar 1200 ms.
B. Pengujian dengan sudut axis $\mathrm{x}$ mendekati nol dan axis y negatif

Grafik yang ditampilkan merupakan grafik sudut(derajat) terhadap waktu(mikro detik). Garis berwarna biru merupakan sudut yang didapat dari axis $\mathrm{x}$ dan garis berwarna jingga merupakan sudut yang didapat dari axis y. Pengujian yang akan dilakukan adalah mengatur agar sudut dari axis $\mathrm{x}$ mendekati nol dan axis y negatif diberikan pada beban.

Hasil pengujian pada Gambar 12 menunjukan osilasi sway pada beban tanpa sistem anti sway dengan menggunakan pengendali manual. Hasil pengujian pada Gambar 13 menunjukan osilasi sway pada beban dengan sistem anti sway dengan menggunakan pengendali manual. Dari Gambar 10 dan Gambar 13 didapat kesimpulan bahwa pada pengujian dengan menggerakan motor ke arah axis $\mathrm{x}$ positif dan y positif, sistem mengurangi waktu osilasi untuk mencapai keadaan stabil sebesar 1880 ms.

Dari 8 pengujian masing-masing akan dibagi menjadi 2 pengujian yaitu pengujian menggunakan sistem anti sway dan tanpa menggunakan sistem anti sway. Tabel 2 merupakan hasil pengujian sistem anti sway menggunakan pengendali manual.
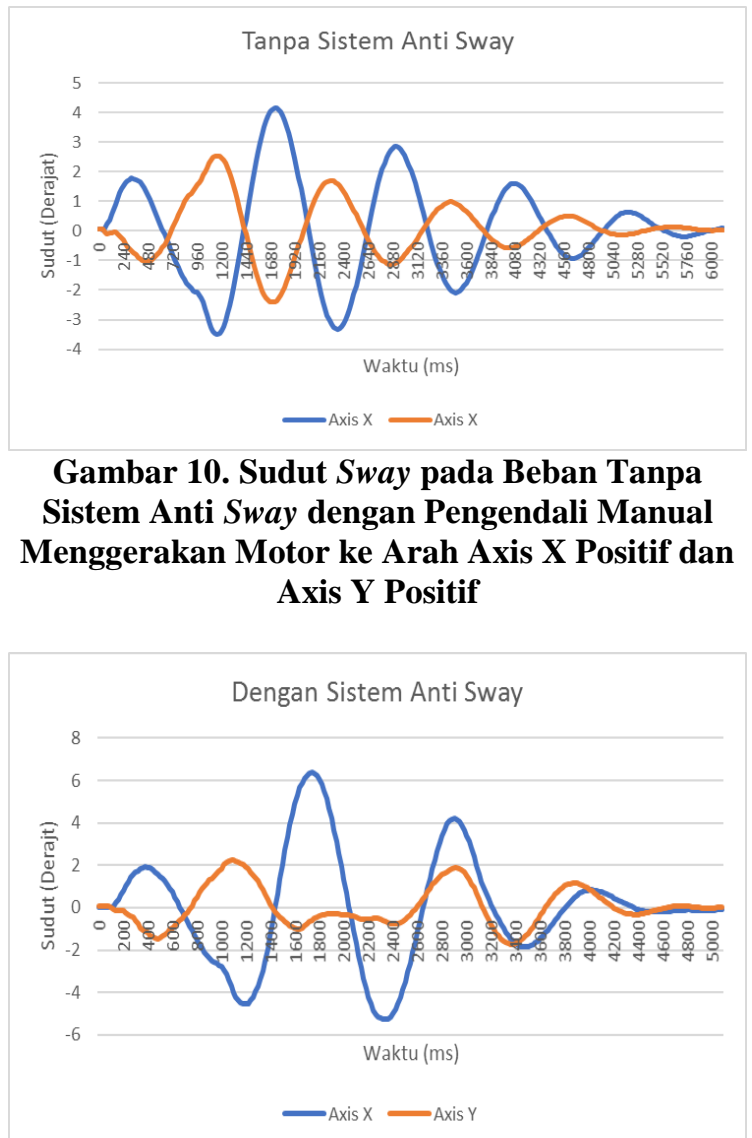

Gambar 11. Sudut Sway pada Beban dengan

Sistem Anti Sway dengan Pengendali Manual Menggerakan Motor ke Arah Axis X Positif dan Axis Y Positif 


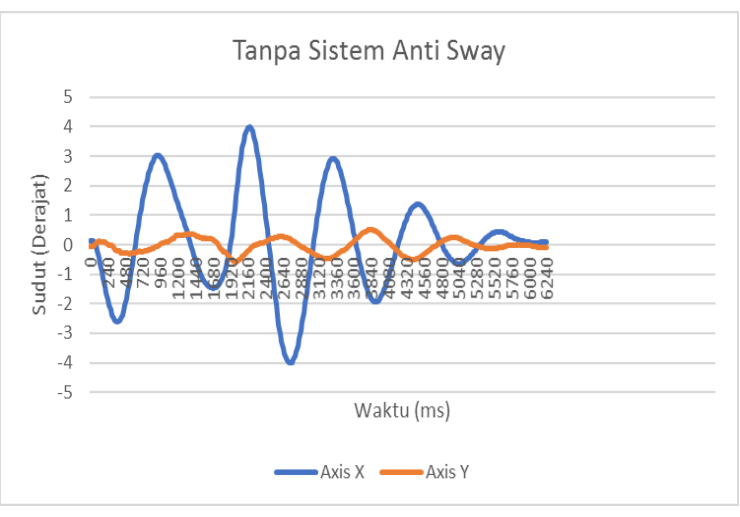

Gambar 12. Sudut Sway pada Beban Tanpa Sistem Anti Sway dengan Pengendali Manual Menggerakan Motor ke Arah Axis Y Negatif

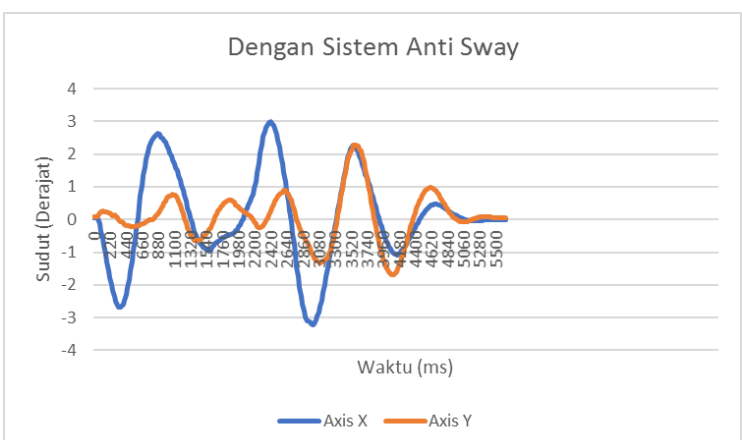

Gambar 13. Sudut Sway pada Beban Dengan Sistem Anti Sway dengan Pengendali Manual Menggerakan Motor ke Arah Axis Y Negatif

Tabel 2. hasil pengujian sistem anti sway tanpa menggunakan pengendali manual

\begin{tabular}{|c|c|c|c|c|}
\hline \multirow[b]{2}{*}{ No. } & \multirow[b]{2}{*}{ Pengujian } & \multicolumn{2}{|c|}{$\begin{array}{l}\text { Hasil Akhir Pengujian } \\
(\mathrm{ms})\end{array}$} & \multirow[b]{2}{*}{$\begin{array}{l}\text { Perbedaan } \\
\text { Waktu (ms) }\end{array}$} \\
\hline & & $\begin{array}{c}\text { Tanpa Sistem } \\
\text { Anti Sway }\end{array}$ & $\begin{array}{c}\text { Dengan } \\
\text { Sistem Anti } \\
\text { Sway }\end{array}$ & \\
\hline 1 & $\begin{array}{l}\text { Nilai axis x positif }\left(8^{\prime}\right) \\
\text { Nilai axis y positif }\left(4^{\prime}\right)\end{array}$ & 7800 & 6400 & 1200 \\
\hline 2 & $\begin{array}{l}\text { Nilai axis } x \text { negatif }\left(-10^{\prime}\right) \\
\text { Nilai axis y negatif }\left(-5^{\prime}\right)\end{array}$ & 9880 & 7800 & 2080 \\
\hline 3 & $\begin{array}{l}\text { Nilai axis x mendekati nol }(0) \\
\text { Nilai axis y negatif }\left(-6^{\prime}\right)\end{array}$ & 9880 & 8000 & 1880 \\
\hline 4 & $\begin{array}{l}\text { Nilai axis x mendekati nol }(0) \\
\text { Nilai axis y positif }\left(10^{\prime}\right)\end{array}$ & 9360 & 8100 & 1260 \\
\hline 5 & $\begin{array}{l}\text { Nilai axis } x \text { positif }\left(12^{\prime}\right) \\
\text { Nilai axis y mendekati nol (-3') }\end{array}$ & 7280 & 6000 & 1280 \\
\hline 6 & $\begin{array}{l}\text { Nilai axis } x \text { negatif }\left(-7^{\prime}\right) \\
\text { Nilai axis y mendekati nol }\left(0^{\prime}\right)\end{array}$ & 6240 & 3240 & 3000 \\
\hline 7 & $\begin{array}{l}\text { Nilai axis x positif }\left(12^{\prime}\right) \\
\text { Nilai axis y negatif }\left(-10^{\prime}\right)\end{array}$ & 10260 & 9800 & 460 \\
\hline 8 & $\begin{array}{l}\text { Nilai axis x negatif }\left(-10^{\prime}\right) \\
\text { Nilai axis y positif }\left(10^{\prime}\right)\end{array}$ & 9240 & 8160 & 1080 \\
\hline
\end{tabular}

Data dari Tabel 2 menunjukan bahwa sistem anti sway bekerja dengan baik, yaitu mengurangi waktu yang diperlukan dari keadaan sway sampai keadaan sudut stabil. Nilai rata-rata perbedaan antara dengan menggunakan sistem anti sway dan tanpa menggunakan anti sway diatas adalah $1.530 \mathrm{~ms}$.

\section{Kesimpulan}

Berdasarkan hasil pengujian dan analisis sistem kendali anti sway overhead crane ini didapat beberapa kesimpulan sebagai berikut:

1. Dalam hasil pengujian dengan menggunakan pengendali manual, nilai selisih rata-rata dalam pengujian axis $\mathrm{x}$ adalah sebesar $750 \mathrm{~ms}$. Yang berarti sistem anti sway bekerja dengan baik didalam pengurangan sway pada pengendalian overhead crane.

2. Dalam hasil pengujian dengan menggunakan pengendali manual, nilai selisih rata-rata dalam pengujian axis y adalah sebesar $630 \mathrm{~ms}$. Yang berarti sistem anti sway bekerja dengan baik didalam pengurangan sway pada pengendalian overhead crane.

3. Dalam hasil pengujian dengan menggunakan pengendali manual, nilai selisih rata-rata dalam pengujian axis $\mathrm{x}$ dan axis $\mathrm{y}$ adalah sebesar $1180 \mathrm{~ms}$. Yang berarti sistem anti sway bekerja dengan baik didalam pengurangan sway pada pengendalian overhead crane.

4. Dalam hasil pengujian tanpa menggunakan pengendali manual, nilai selisih rata-rata dalam pengujian axis $\mathrm{x}$ adalah sebesar $770 \mathrm{~ms}$. Yang berarti sistem anti sway bekerja dengan baik dalam mengurangi sway pada pengendalian overhead crane.

5. Dalam hasil pengujian tanpa menggunakan pengendali manual, nilai selisih rata-rata dalam pengujian axis y adalah sebesar $1570 \mathrm{~ms}$. Yang berarti sistem anti sway bekerja dengan baik dalam mengurangi sway pada pengendalian overhead crane.

6. Dalam hasil pengujian tanpa menggunakan pengendali manual, nilai selisih rata-rata dalam pengujian axis $\mathrm{x}$ dan axis $\mathrm{y}$ adalah sebesar $1890 \mathrm{~ms}$. Yang berarti sistem anti sway bekerja dengan baik dalam mengurangi sway pada pengendalian overhead crane.

\section{Daftar Pustaka:}

[1] Susanto, Erwin. "Kontrol Proporsional Integral Derifatif (PID) Untuk Motor DC Menggunakan Personal Computer”. Institut Teknologi Telkom Bandung., 2008.

[2] Physics 15c, Laboratory 1. 2016. The Pendulum. ipl.physics.harvard.edu/wpuploads/2013/03/15c_s07_1.pdf. 